\title{
Introducing Beginning Reading Using Phonics Approach
}

\author{
Masello Hellen Phajane \\ Department of Early Childhood Education (ECE) \\ University of South Africa (UNISA),PO Box 392 Pretoria 0003 \\ Email: phajamh@unisa.ac.za
}

\section{Doi:10.5901/mjss.2014.v5n10p477}

\begin{abstract}
In order for sound reading competence to be established in South African schools, it is essential to understand the facts that hinder the development of reading skills and avoid or minimize them where possible, at the same time nurturing those factors that promote skilled reading literacy, Kuhn \& Stahl (2003:3-21). The paper therefore, focused on the teaching of beginning reading Sepedi in the Grade 1 classrooms using the phonics approach. This is a case study that was conducted at Keletso Primary School at Ramogodi village, situated in the North West Province of South Africa. Qualitative research was employed in this study. Purposive sampling was also used as an approach of sample selection. Based on the data collected, it is important to recognize that the goals of phonics approaches are to provide children with key knowledge and skills and to ensure that they know how to apply that knowledge in their reading and writing.
\end{abstract}

Keywords: Phonics, reading, sounds, words, sentences, children, teachers, approach, children.

\section{Introduction}

The Department of Based Education (DBE) (2010:22) has recognised that there are unique challenges facing learners who are learning to read in a Home language. Some issues that Foundation Phase teachers need to consider include: differences in sound or symbol relationships; differences in sentences structure; limitation in oral vocabulary; and the need for explicit teaching of phonics. In light of these differences, the DBE (2010:24) states that words and sentences should be taught informally at first, items should be labelled in the classroom; picture stories, graded readers and sight in (Setswana), the home language (DoE 2008:10-11).

Teaching phonics (and related phonics skills, such as phonemic awareness) is a more effective way to teach children early reading skills than is embedded phonics or no phonics instruction. The National Reading Panel (NRP) (2004:27) found that phonics instruction is an effective approach of teaching reading for children from kindergarten through $6^{\text {th }}$ grade, and for all children who are having difficulty in learning to read. They also found that phonics instruction benefits all ages in learning to spell. They also reported that teachers need more education about effective reading instruction, both pre-service and in-service.

In her book, Allington (2005:15) asserted that existing scientific research supported that phonics is an effective approach for teaching learners to read at the word level. Allington (200:16) argued strongly that the phonics and the whole language advocates are both right, and that phonics is an effective way to teach children the alphabetic code, building their skills in decoding unknown words. By learning the alphabetic code early, she argued, children can quickly free up mental energy they had used for word analysis and devote this mental effort to meaning, leading to stronger comprehension earlier in elementary school. Thus, she concluded, phonics instruction is a necessary component of reading instruction, but not sufficient to teach children to read. National Reading Panel (2004:18) (NRP), this result matched the overall goal of whole language instruction and supported the use of phonics for a particular subset of reading skills, especially in the earliest stages of reading instruction. Yet the argument about how to teach reading, eventually known as "the Great Debate," continued debated.

Among other results, the report includes the finding that phonics instruction improves children's ability to identify words. It reports that useful phonics strategies include teaching children the sounds of letters in isolation and in words, and teaching them to blend the sounds of letters together to produce approximate pronunciations of words. It also states that phonics instruction should occur in conjunction with opportunities to identify words in meaningful sentences and stories Gray \& McCutchen (2006:39). 


\section{What is Phonics?}

Phonics is a way of decoding written letters and spoken sounds. This approach to learning to read encourages children to decode words by sounds, rather than by recognising whole words Bald (2007:10). In the early years, teaching focuses on synthetic phonics, where words are broken up into the smallest units of sound (phonemes). Children are taught the letters (graphemes) that represent these phonemes and also learn to blend them into words. At its simplest, children are taught to read the letters in a word like e-m-a (stand), and merge them to pronounce the word ema. But, of course, phonemes can be represented by one, two, three or four letters (for example, e-me (standing), ra-ga (kick), fo-ro-ko (fork), and so forth together to make simple words. Children are systematically taught around 40 phonic sounds and the combination of letters used to represent each sound Bald (2007:10).

For children to learn the phonics approach they need phonically written books using regular words that are interesting to young children. Each word must be sounded out by the child in order to achieve the highest level outcome. Learning the sounds and their blends may be disinteresting for young children so you should keep it short and entertaining. Often children are so busy concentrating on sounding the words and blending the sounds that they don't learn the meaning of the word, making it boring for them Cunningham \& Allington (2007:133). Ensure you explain the meaning or expound on the words to keep interest and enthusiasm for learning. You can introduce one letter a day or one letter a week, but one letter a day approach works quite well and it does not become boring, whereas one letter a week tends to drag out and the child often loses the plot halfway through. This in turn gives you a sense of failure and you will become bogged down.

Don't be disheartened if two or three days or even a week is needed to master one letter, students will improve and before long you will find there is no stopping their young brain. Children are natural learners and are more than willing to please you thus doing well in their learning experience Chall (1999:34). Using the phonics approach, most children will learn to read basic words and sentences within three to six months. It supplies the student with tools to expand their vocabulary.

It is important to recognize that the goals of phonics instruction are to provide children with key knowledge and skills and to ensure that they know how to apply that knowledge in their reading and writing. In other words, phonics teaching is a means to an end Goouch \& Lambirth (2007:23). To be able to make use of letter-sound information, children need phonemic awareness.

\section{Phonics Instructions}

Phonics instruction teaches children that there is a relationship between the letters of written language (graphemes) and the individual sounds of spoken language (phonemes) Ma, X \& Crocker (2007:53). Regardless of what some critics say, the goal of phonics instruction is to make children understand that there is a systematic and predictable relationship between written letters and spoken sounds. Knowing these relationships will help children recognize familiar words accurately and automatically, and to decode new words. A child must learn phonic information to the point of it becoming automatic. This contributes to children's ability to read words in isolation and in connected text. But the phonics instruction is a means to an end, not an end in itself, Rose (2006:31).

Stahl (2004:35), using language borrowed from Durkin, defines phonics as "any approach in which the teacher does or says something to help children learn how to decode words". There are numerous approaches to teach phonics, viewed through a broad lens. These can be classified as analytic and synthetic approaches Stahl, (2004:57). The synthetic approaches begin with learning letter sound relationships and blending them to create words r/a/t/a then ra-ta (love). Bald (2007:18) the synthetic phonics approach is where the learner has to sound out and blend letters to form words, some examples for this statement according to the researcher's own experience can be as follows (e.g. s-e-k-o-l-o then sekolo (school), from parts to the whole).

Stahl, (2004:57) analytic approaches have children analyze sounds in words that i.e. they start with a word and take it apart for example, the word rata (love) is taught by first reviewing the four sounds r/a/t/a, (love). Then after the children say each sound, they blend the three sounds together. He concluded that one type of approach is not superior to the other. Bald (2007:18) the analytic approach is where the learner has to break words into letter-sound segments ((e.g. sekolo then s-e-k-0-l-o (school), from parts to whole) and the spelling-based approach is where the learner has to sort words by spelling patterns.

Stahl's (2004:357) study as well as the findings of the National Reading Panel (NRP) (2000:82) concluded that one type of approach is not superior to the other. Furthermore, the NRP report suggested that phonics instruction is most effective in first grade. In considering the most effective way to teach phonics, Stahl and Duffy - Hester, (2004:598) 
propose the following principles;

* Good phonics instructions should develop phonological awareness.

* Good phonics instruction should provide a thorough grounding letters.

* Good phonics instruction should not teach rules, need not use worksheets, should not dominate instruction, and does not have to be boring.

* Good phonics instruction reads provides sufficient practice in reading words.

* Good phonics instruction reads to automatic word recognitions.

* Good phonics instruction is one part of reading.

\section{Literature Review}

The Grade 1 curriculum indicates that when teaching about phonics, the "Grade 1 teacher must first test to see if learners know the sounds of letters," National Literacy Trust (2006:31). Although the syllabus points out that when children fail to master phonics, the teacher must teach them the vowels and then consonants, it does not provide any guidance on how to do this. Thus the syllabus is open to misinterpretation. This means that teachers teach 'vowel order' because of the direction they get from the curriculum itself. There is great inconsistency between what the curriculum says and what happens on the ground and what the literature says, Stahl (2004:335)

According to Brand (2004:18) phonics instruction is a way of teaching reading that stresses the acquisition of lettersound correspondences and their use in reading and spelling. The primary focus of phonics instruction is to help beginning readers understand how letters are linked to sounds (phonemes) to form letter-sound correspondences and spelling patterns and to help them learn how to apply this knowledge in their reading. Phonics instruction may be provided systematically or incidentally. Brand (2004:18) the hallmark of a systematic phonics approach or program is that a sequential set of phonics elements is delineated and these elements are taught along a dimension of explicitness depending on the type of phonics approach employed. Conversely, with incidental phonics instruction, the teacher does not follow a planned sequence of phonics elements to guide instruction but highlights particular elements opportunistically when they appear in text (Gordon \& Brown 2004:6).

\section{Research Methodology}

This research is positioned as a qualitative case study, and according to De Vos, Delport; Fouche and Strydom (2006:34), it meets the interpretive researcher's purpose of understanding situations that are complex. This research is based on the information collected at schools that are complex networks in which staff members interact at various levels. Levin \& Rock (2003:43) are of the opinion that interpretive social research emphasises the complexity of human beings, and attempts to construct and understand their worlds. As mentioned before, the researchers of this paper collected data from one Foundation Phase School in North Province of South Africa. The participants were purposively selected. All of the participants were Foundation Phase teachers who had attended workshops on teaching reading and who were involved in its implementation. One teacher was observed and was later interviewed on the teaching of beginning reading using phonics approach. In order to establish how the research was approached, observations and interviews were used to collect many views.

\section{The Organisation of the School}

Keletso Primary School is located in the rural area of Mmakau about 3 kilometers from the Brits District; it does not have a high enrolment of learners. The drop in the enrolment was the result of political violence that had disrupted schools in 1993, and this school was located in the area that had received the most heat of violence. Windows were still broken and some classroom and office walls were under repairs. Almost half of the classroom wall from the ground up consisted of unpainted red bricks. The top half was roughly plastered and painted with white wash.

Against this background, most parents were still afraid of sending children to schools near that area, while others had not returned to their burned places of residence after fleeing. The school had a staff of 15, but because the enrolment had dropped, some children had flocked to other schools under Garankua Circuit, which were less affected by violence. Three teachers were temporarily traded/ loaned, and sent to schools with most need, until the situation normalized. For this reason, the school accommodates from grade one to five. In the grade one classroom there were 35 children, who were seated in twos and threes on desks of tightly packed rows. The desks were not easily movable since the desk tops and the seats were connected. 
Although classroom space is not a problem, the class sizes are relatively small. It was the only school with a small library containing learner's books, but the library was not integrated into the daily activities of the school. A very relaxed atmosphere seemed to prevail at the school. At the school, the principal assigned the researcher Mama Kelello, who was senior in the years of teaching experience in the first grade and was older in age. For a number of years like most of her colleagues in the school she taught beginning reading using the Phonics Approach.

The Head of Department (HOD) Mama Bokang was monitoring the progress of previous year's bridging period class in the first grade. She said that she wanted this class (grade 1) to get a good teacher. It was therefore important to the HOD that first grade children who had been in the bridging period, the previous year pass Sepedi because, it is the foundation. She stressed that a child who did not do well in Sepedi had a problem in reading and writing in other subjects that were written in Sepedi. Without a good foundation in Sepedi, the learner will not be promoted to the second grade even if she or he can get $100 \%$ in mathematics. For this reason, the HOD wanted this class to be taught by an experienced teacher like Mama Kelello.

Her class has thirty five learners, twenty girls and fifteen boys with their tables arranged in groups. The wall is also decorated with number charts, alphabet charts, charts about the days of the week, months of the year, phonic charts, for incidental reading and many more. Sometimes during her reading lessons, she would refer to phonic charts and days of the week, which she treats as what she calls 'rhymes' and the learners sing them. During the day the researcher observed her lesson, she had a large class of seventy (70) learners, made up of her own class, and another class belonging to Grade 1 teacher who was on maternity leave. This was a serious threat to classroom management due to class size, but the teacher was able to control learners by giving them enough activities to keep them busy.

\section{Introducing Beginning Reading using the Phonics Approach}

As described earlier, for this reason, Mama Kelello was a good choice; she fits the criteria of teachers, in that she was familiar with all the issues that were important in teaching beginning reading to a wide range of children during the first year. In Keletso School, the researcher decided to start observing and interviewing teachers who were involved in school readiness. Then she would see and hear from other teachers what and how they continued to teach beginning reading when formal instruction was offered after school readiness, using phonics instruction Department of Education (2008:13) (DoE).

The researcher visited Mama Kelello's class for an entire day and held observations and interviews with her during that time. Mama Kelello taught school readiness to all children during the first three months, after children entered the first grade at ages five and a half years and above. After screening for readiness during the first two weeks, most of the children at Keletso School were placed in the school readiness program for the first 12 weeks, while one class was allowed to begin formal instruction right from the beginning. During the first quarter (12 weeks) of the schools readiness programme, teachers sorted children in their classes into groups depending on activities they could perform. For this reason the researcher spent most time observing and interviewing her.

Mama Kelello, I start with a poster description so as to introduce readiness programme which is the programme that prepares children for formal learning, at the beginning of the year, children are trained on how to move their fingers, write in the air and also writing in the sand, it prepares learners emotionally and socially. In the mean time, she made references to other teachers that had similarities or differences from hers, which the researcher followed up by observing and interviewing those teachers.

She assessed learner's readiness for formal instruction in her class by using formal texts, such as distinguishing colors, matching and transcribing words in flash cards etc. Mama Kelello used these activities as part of determining children who were ready for formal instruction and reading. Those children who could accurately recognize words and read them aloud when accompanied by pictures were then grouped as ready. Those children who were ready were then assigned to different grade one classes and teachers began formal instruction in reading and other first grade work. Those who were not ready formed, a class called the "bridging period" which continued with the school programme for the whole year.

She further explained that; in black schools a leaner could not be promoted to the second grade if she failed to read and write in Sepedi (her home language). It is therefore important to understand what and how the first three months of school helped or hindered the children's development in learning to read. 


\section{Lesson Activities and Methods}

\subsection{Day: 1}

Mama Kelello was happy to show us her record book, in which she regularly made notes about children's performance in Setswana, the children's individual reading records, which included detailed comments from the teacher, and the results from the standardised reading tests she administers quarterly.

Mama Kelello included displays of topic and fiction books, labels on all equipment and posters telling children how to change library books. The displays on the walls were at the children's eye level and contained questions about a poster as well as work by the children. A set of stories written as books and bound by the children were available for others to read. A listening centre, in the book area, was used by some of the children who were browsing among the books and a good range of book stories were available.

In the lesson we observed, Mama Kelello started by doing a big book session with all the children in the class, which took about 20 minutes. The children clearly knew the routine and settled immediately. They were attentive and enthusiastic throughout both sessions. Mama Kelello started by asking children questions about the cover of the book, such as: Le nagana gore ke mabapi le eng? (What do you think it will be about?), Lo itsi jang (How do you know?) and picked up their responses about the title, picture and author. She repeated these terms and added illustration when she asked the children more about their ideas.

Mama Kelello read the book in unison with the class, pausing before the final word of each line to see whether they could guess the rhyming word. Within a page or two all the children were eagerly offering guesses. Mama Kelello also pointed out the beginning sound of $t \mathrm{l}$ and ts words and ng pre-fixes, which seemed to be a focus for some children. After the first reading, children were picked to read out a line each.

She asked children questions about the story and what they thought about it, commenting on the funny bits and laughing with the children. Using the chalkboard she wrote up some words and asked the children for other words which rhymed with them. At first only a few children made guesses, but within four or five guesses the majority of the children seemed to have ideas to offer. Mama Kelello then picked out some words starting with ng (ngala, nganga, ngapa,) and collected more from the children in the same way, asking the children to come up and write them on the chalkboard.

Following the big book session, Mama Kelello set the children working in three groups. One group went to browse among the books and read individually with a class mate. Another group went off to work on a comprehension passage related to the big book they had just read, with the support of a group. Mama Kelello said that all the children would complete these activities but at different times, so that the extra assistance of helpers and parents could be used effectively.

The children were asked to read the passage carefully and given a few moments to do so. Individuals then volunteered to read it out sentence by sentence, saying something for each blank space. Mama Kelello pointed out the full stops and capitals around each sentence. Mama Kelello read the passage through aloud and then asked the children what it was about. They then worked in two's and three's to make a list of the words which would fit into the blanks. This took about 10 minutes. Mama Kelello then went through the passage evaluating all answers and asking the children to evaluate themselves against the questions: A seo se a thaloganyega naa? (Does that make sense?): A e utlwala sentle ga e le jalo naa? (Does it sound right like that?) Mama Kelello also repeatedly asked children how they had worked out a word. One child said he had read over the spaces to see what was needed, by which he meant reading the text with appropriate intonation and a slight pause at each gap. Mama Kelello asked others if they could do this. She then demonstrated how you could read over a space to see what would make sense and sound right in the space.

Children were keen to defend their choice of words and say why alternatives did not make sense or sounded wrong. Mama Kelello tried out all the suggestions and accepted answers with appropriate meanings which were the right parts of speech, but allowed several possible answers in some spaces, saying which ones she preferred and why. Finally, Mama Kelello read the whole passage with the spaces filled, reading out the alternatives, congratulated the children and reminded them that reading over a space or word they didn't know was another way to help them guess what would make sense and what would sound right.

When Mama Kelello was asked about this session she identified the literacy content as "a big book session, with rhymes and ng as the focus". She said she had also emphasised three particular sounds as she was concerned about a small group of children who were still having difficulty with them. The second part of the session she called: "reading a story beginning to practice using semantic and syntactic reading cues". She identified the children who could do rhymes, ng words and use a full range of reading cues to some extent and those who were still starting on these skills. 


\subsection{Day: 2}

Mama Kelello used the phonic method to teach reading, and reiterated the significance of sounding words, reading should be taught by using the phonic method, and if children know how to pronounce words in phonics, they will read with ease Strickland \& Morrow (2006:26). The researcher observed that a letter was taken from the reading book Mathasedi text to teach sound and phonics. The tl sound was taught for the whole week, but using different activities. The teacher introduced the sound by giving a sentence with repeated sound in it, e.g. ntlo e tletse ka di tlou tse ntle (the house is full of beautiful elephants). The teacher repeated the sentence several times by using pictures and gestures and asked the children to identify the repeated sound they heard. They child identified the tl sound.

One child instead identified the ts sound, but this was not wrong because the ts sound was also repeated several times. The teacher praised that child because she was very observant, but then told the child that they were going to learn the tl sound. The children were requested to give all the words they know which had the ts sound. The teacher wrote them on the chalkboard as children name them, e.g. tlou (elephant), tletse (full), ntle (beautiful). The teacher read the words with children and later allowed them to read them alone. They were given homework to cut out pictures of all the words with the tl sound.

In that lesson the researcher observed, after the child has given a word. Mama Kelello asked all the children to repeat it. In the process they were identifying different words that made up the sentence. For instance, in the sentence "ntate o bona ntlo e ntle" (father sees a beautiful house), Mama Kelello used her finger to distinguish words such as ntate (one), o (two), bona (three), ntlo (four), e (five), ntle (six), (father (one), sees (two), a (three), beautiful (four), house (five). She then emphasized, do you see spaces in between words? (as represented by her fingers in the demonstration) she stressed that right from the beginning, children learn about the different sentence parts before they could even write it down. It was after the demonstration and explanation that she wrote the sentence and children were counting the words as they read it out loud from the chalkboard. She maintained that; right from the beginning, the idea was then instilled in the learner's head that words are written separately just as they come out of the mouth in speech. In this approach, the learner thinks for himself.

Different Activities were given to children as follows: Children were given activities to write a word for each picture; another group was given an activity to fill in the missing letter; another of writing a simple sentence using the words given; another of tracing on the dotted words given. DBE (2010:30) argue that when planning a differentiated teaching lesson, the content of the instruction should include the same broad concept, principles and skills for all children, for instance, in the example of teaching the tl sound, children were given different activities, but the main content was on the sound. Another example was on storytelling, the teacher told the story using facial expressions and gestures, and varied the tone of her voice. Children were enjoying the story and could even dramatise it.

\section{Concluding Remarks}

The DoE (South Africa, 2008:67) states that in applying teaching methods educators should bear in mind that there is no single classroom in which all learners will be exactly the same or learn in the same way and at the same pace. As a result, they were required to be creative in the use of a variety of teaching methods to reach all the learners. The respondents identified different methods that they were using to teach in inclusive classrooms, such as storytelling, songs, rhymes, dramatisation, learning through play as well as questions and answers: "We also use storytelling, whereby an educator tells a story, using pictures and a big book for that matter, and we also allow the learners to retell the story and also dramatise it"; "Some learners learn best through songs; others like rhymes; and others can understand and cope by listening while the educator is teaching"; "Some can even formulate a game from an activity, especially in Numeracy, when they count. The learners grasp a lot as they play. It is learning through play".

Teaching through songs, rhymes, dance, poems, and acting is much fun. For educators this means that when they are planning lessons they need to use visual materials (such as posters, pictures, drawings); to use tasks that involve discussion (listening and speaking); and to provide opportunities for movement of some form (e.g. drama and dance). The respondents added that they accommodated all the learners' learning needs and styles of learning: "Some learners learn best through songs; others like rhymes; and others can understand and cope by listening while the educator is teaching. So we use songs, rhymes, colourful pictures and real objects when we teach". They said that they usually used gestures, and body and facial expression when they taught so that the learners would better understand.

The lessons emphasised the role of sounds in reading and writing and placed emphasis upon children's developing understanding of how the sound system of language could be used to offer access to stories, messages and other texts. 


\section{References}

Allington, R.L. (2005). What really matters for struggling readers: Designing research-based programs (2nd d.) Boston: Allyn Bacon.

Bald, J. (2007). Using phonics to teach reading and spelling London: Paul Chapman.

Brand, M. (2004). Word savvy; integrating vocabulary, spelling and word study. Portland, ME: Stenhouse.

Chall, J.S. (1999). Some thoughts on reading research: Revisiting the first-grade studies.

Reading Research Quarterly, 34(1):8-10.

Cunningham, P.M., \& Allington, R.L. (2007). Classrooms that work. They can all read and write. New York: Pearson Education.

Department of Basic Education (DBE), (2010). Curriculum and Assessment Policy Statement (CAPS). Pretoria: DBE.

Department of Education. (2008). Revised National Strategy on screening, identification, assessment and support. Pretoria: Department of Education.

De Vos, AS. Strydom, H. CB \& Delport, CSL (Eds.) (2006). Research at grassroots. Pretoria: Van Schaick.

Goouch, K. \& Lambirth, A. (2007). Understanding phonics and the teaching of reading. London: McGraw-Hill.

Gray, A. \& McCutchen, D. (2006). Young readers' use of phonological information: Phonological awareness, memory and comprehension. Journal of Learning Difficulties, 9(4):325-333.

Kuhn, M. R., \& Stahl, S. A. (2003). Fluency: A review of developmental and remedial practices. Journal of Education Psychology, 95(1):3-21.

Levin, B.B., \& Rock, T.C. (2003). The effect of collaborative action research on pre-service and experienced educator partners in professional development schools: Journal of Educator's professional development. Department of Education and training: Australia.

Ma, X., \& Crocker, R. (2007). Provincial effects on reading achievement. The Alberta Journal of Education Research, 53(2)87-109.

National Literacy Trust, 2006, Reading for pleasure; A research overview.

National Reading Panel. (2004). Teaching children to read: An evidence-based assessment of the scientific research literature on reading and its implications for reading instruction. Washington, DC: National Academy Press.

Rose, D. (2006). Teacher Training Manual. Literacy Across the curriculum. Sydney. Learning to Read.

Reading to Learn.

Stahl, K.A.D \& Duffy-Hester, (2004), Proof, practice, and promise: Comprehension strategy instruction in the primary grades. The Reading Teacher, 57(?):598-609.

Strickland, D.S., \& Morrow, L.M. (2006). Beginning reading and writing. (Eds.). New York: Teachers College Press and Newark, DE: International Reading Association. 